\title{
A NMR-Based Carbon-Type Analysis of Diesel Fuel Blends from Various Sources
}

\section{JT Bays}

DL King

May 2013

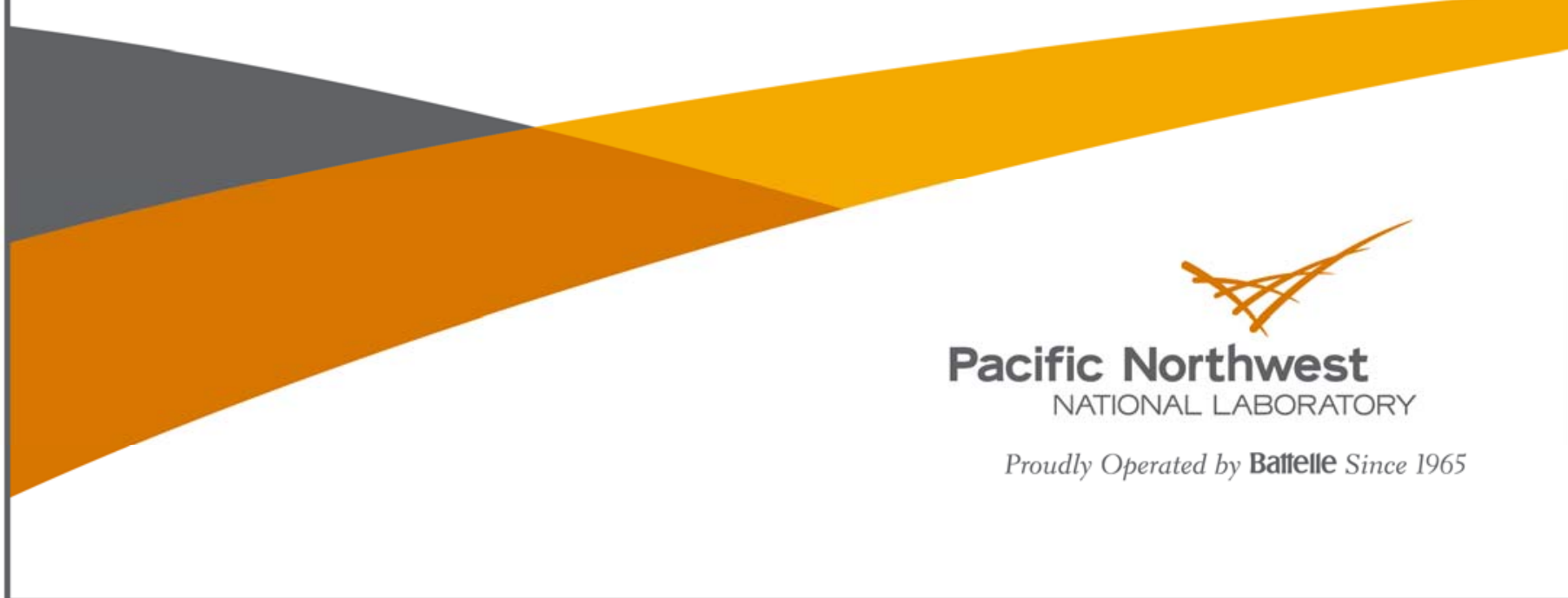




\title{
DISCLAIMER
}

This report was prepared as an account of work sponsored by an agency of the United States Government. Neither the United States Government nor any agency thereof, nor Battelle Memorial Institute, nor any of their employees, makes any warranty, express or implied, or assumes any legal liability or responsibility for the accuracy, completeness, or usefulness of any information, apparatus, product, or process disclosed, or represents that its use would not infringe privately owned rights. Reference herein to any specific commercial product, process, or service by trade name, trademark, manufacturer, or otherwise does not necessarily constitute or imply its endorsement, recommendation, or favoring by the United States Government or any agency thereof, or Battelle Memorial Institute. The views and opinions of authors expressed herein do not necessarily state or reflect those of the United States Government or any agency thereof.

\author{
PACIFIC NORTHWEST NATIONAL LABORATORY \\ operated by \\ BATTELLE \\ for the \\ UNITED STATES DEPARTMENT OF ENERGY \\ under Contract DE-AC05-76RL01830
}

Printed in the United States of America
Available to DOE and DOE contractors from the Office of Scientific and Technical Information, P.O. Box 62, Oak Ridge, TN 37831-0062; ph: (865) 576-8401 fax: $(865) 576-5728$
email: reports@adonis.osti.gov
Available to the public from the National Technical Information Service 5301 Shawnee Rd., Alexandria, VA 22312 ph: (800) 553-NTIS (6847) email: orders $a$ ntis.gov $<$ http://www.ntis.gov/about/form.aspx> Online ordering: http://www.ntis.gov




\section{A NMR-Based Carbon-Type Analysis of Diesel Fuel Blends from Various Sources}

JT Bays
DL King

May 2013

Prepared for

the U.S. Department of Energy

under Contract DE-AC05-76RL01830

Pacific Northwest National Laboratory

PO Box 999

Richland, Washington 99352

Phone: (509) 375-6900

Email: tim.bays@pnnl.gov

DOE Technology Development Manager: Kevin Stork

Phone: (202) 586-8306; Email: kevin.stork@ee.doe.gov 



\section{Summary}

In collaboration with participants of the Coordinating Research Council (CRC) Advanced Vehicle/Fuels/Lubricants (AVFL) Committee, and project AVFL-19, the characteristics of fuels from advanced and renewable sources were compared to commercial diesel fuels. The main objective of this study was to highlight similarities and differences among the fuel types; that is, ultra-low sulfur diesel (ULSD), renewables, and alternative fuels, and among fuels within the different fuel types. This report summarizes the carbon-type analysis from ${ }^{1} \mathrm{H}$ and ${ }^{13} \mathrm{C}\left\{{ }^{1} \mathrm{H}\right\}$ nuclear magnetic resonance spectroscopy (NMR) of 14 diesel fuel samples. The diesel fuel samples come from diverse sources and include four commercial ULSDs, one gas-to-liquid (GTL) diesel fuel, six renewable diesel (RD) fuels, two shale oil (SO)-derived diesel fuels, and one oil sands (OS)-derived diesel fuel. Overall, the fuels examined fall into two groups. The two shale oil-derived samples and the oil-sand-derived sample closely resemble the four commercial ULSDs, with SO1 and SO2 most closely matched with ULSD1, ULSD2, and ULSD4, and OS1 most closely matched with ULSD3. As might be expected, the renewable diesel fuels, with the exception of RD3, do not resemble the ULSD fuels because of their very low aromatic content, but more closely resemble the GTL sample in this respect. RD3 is significantly different from the other renewable diesel fuels in that the aromatic content more closely resembles the ULSD fuels. Fused-ring aromatics are readily observable in the ULSD, SO, and OS samples, as well as RD3, and are noticeably absent in the remaining RD and GTL fuels. Finally, ULSD3 differs from the other ULSD fuels by having a significantly lower aromatic carbon content and higher cycloparaffinic carbon content. In addition to providing important comparative compositional information regarding the various diesel fuels, this report also provides important information about the capabilities of NMR spectroscopy for the detailed characterization and comparison of fuels and fuel blends. 



\section{Acknowledgments}

The authors gratefully acknowledge the U.S. Department of Energy, Energy Efficiency and Renewable Energy, Office of Vehicle Technology, for their programmatic support. We sincerely appreciate the valuable interactions we have had with members of the Coordinating Research Council (CRC) Fuels for Advanced Combustion (FACE) Working Group and other Advanced Vehicle Fuels and Lubricants Committees.

The authors also thank Drs. John C. Linehan, Wendy J. Shaw, and Molly O'Hagan for their helpful discussions and advice. 



\section{Acronyms and Abbreviations}

$\begin{array}{ll}\text { AVFL } & \text { Advance Vehicle/Fuels/Lubricants } \\ \text { COSY } & \text { correlation spectroscopy } \\ \text { CRC } & \text { Coordinating Research Council } \\ \text { GTL } & \text { gas-to-liquid } \\ \text { HMBC } & \text { heteronuclear multiple bond correlation } \\ \text { HSQC } & \text { heteronuclear single quantum coherence } \\ \text { INADEQUATE } & \text { Incredible Natural-Abundance DoublE-QUAntum Transfer Experiment } \\ \text { NMR } & \text { nuclear magnetic resonance } \\ \text { NOE } & \text { nuclear Overhauser enhancement } \\ \text { OS } & \text { oil sands } \\ \text { PNNL } & \text { Pacific Northwest National Laboratory } \\ \text { RD } & \text { renewable diesel } \\ \text { SO } & \text { shale oil } \\ \text { TOCSY } & \text { total correlation spectroscopy } \\ \text { USLD } & \text { ultra-low sulfur diesel fuels }\end{array}$





\section{Contents}

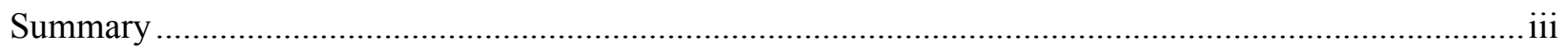

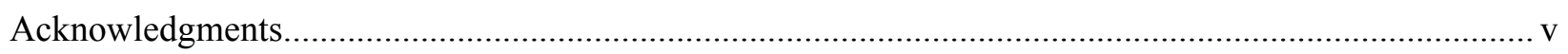

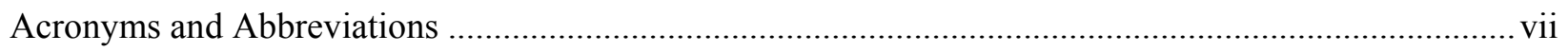

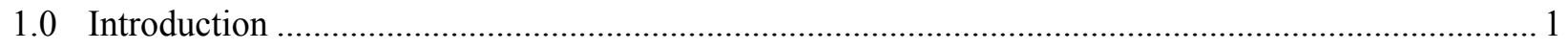

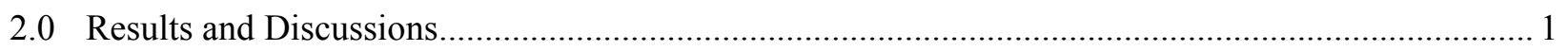

2.1 Comparison of Ultra-Low Sulfur Diesel Samples ............................................................ 2

2.2 Comparison of Diesel Samples Derived from Shale Oil (SO) and Oil Sands (OS)

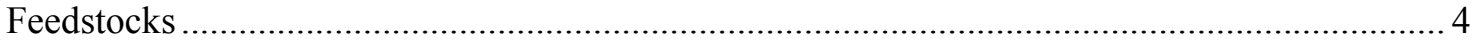

2.3 Comparison of Renewable Diesel (RD) and Gas-to-Liquid (GTL) Samples............................. 6

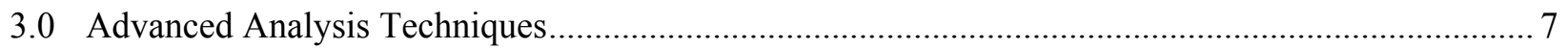

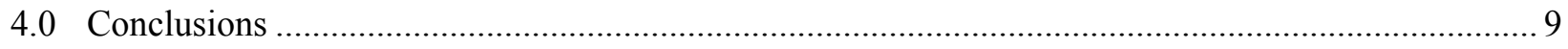

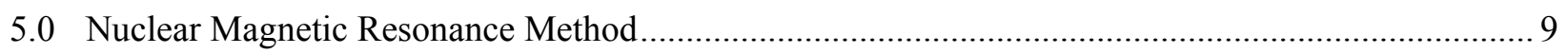

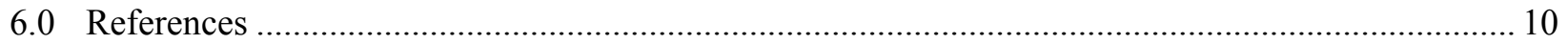

Appendix A - Complete NMR and NMR-Derived Data Tables …..................................................... A.1 


\section{Figures}

1 Single-bond, Proton-Carbon Correlation (HSQC) NMR Spectra of Fuels 8

\section{Tables}

1 Comparison of Carbon-Type Analyses of Ultra-Low Sulfur Diesels (ULSD), Normalized by Carbon Type

2 Summary of Ultra-Low Sulfur Diesel (ULSD) Chemical Structure Characteristics from ${ }^{13} \mathrm{C}\left\{{ }^{1} \mathrm{H}\right\}$ NMR, Normalized by Percent Carbon Type 3

$3 \quad{ }^{1}$ H NMR Aromatic Region for Ultra-Low Sulfur Diesel (ULSD) Fuels, Breakdown of Fused, Protonated Aromatic Ring Hydrogens, Percent Results Normalized by Hydrogen Type

4 Summary of Carbon-Type Analyses of Diesel Samples Derived from Shale Oil (SO) and Oil Sands (OS) Feedstocks, Normalized by Carbon Type.

5 Summary of Diesel Samples Derived from Shale Oil (SO) and Oil Sands (OS) Feedstocks Chemical Structure Characteristics from ${ }^{13} \mathrm{C}\left\{{ }^{1} \mathrm{H}\right\}$ NMR, Normalized by Percent Carbon Type

$6 \quad{ }^{1}$ H NMR Aromatic Region for Shale Oil (SO) and Oil Sands (OS) Derived Fuels, Breakdown of Fused, Protonated Aromatic Ring Hydrogens, Percent Results Normalized by Hydrogen Type

7 Comparison of Carbon-Type Analyses of Renewable Diesel (RD) and a Gas-to-Liquid (GTL) Fuels, Normalized by Carbon Type

8 Summary of Renewable (RD) and Gas-to-Liquid (GTL) Diesel Chemical Structure Characteristics from ${ }^{13} \mathrm{C}\left\{{ }^{1} \mathrm{H}\right\}$ NMR, Normalized by Percent Carbon Type

$9{ }^{1}$ H NMR Aromatic Region of Renewable Diesel (RD) and a Gas-to-Liquid (GTL) Fuels, Breakdown of Fused, Protonated Aromatic Ring Hydrogens, Percent Results Normalized by Hydrogen Type 


\subsection{Introduction}

Alternative and renewable fuels are likely to become important contributors to vehicle fuels as they become more commercially available. Already available are fuels derived from Canadian oil sands, an alternative fuel source, with shale oils becoming increasingly available as extraction and processing techniques become more cost effective. Renewable biodiesel fuels are also drawing increased interest because conventional refinery hydroprocessing methods can be used, making the fuels more compatible with existing infrastructure, consequently making them more attractive to fuel producers. In using fuels from alternative and renewable sources directly, or blending these sources with more conventional fuel feedstocks, it is essential to understand from a molecular level the performance properties that each fuel brings. Our goal is to use molecular structure to accurately forecast the fuel performance properties, allowing the resulting fuels to be optimally blended. This understanding will lead to a more reliable fuel product that can be derived from multiple sources, toward the goal of increasing fuel availability and lowering cost.

This report summarizes the carbon-type analysis from ${ }^{1} \mathrm{H}$ and ${ }^{13} \mathrm{C}\left\{{ }^{1} \mathrm{H}\right\}$ nuclear magnetic resonance (NMR) spectroscopy of 14 diesel fuel samples, as analyzed by Pacific Northwest National Laboratory (PNNL), Richland, Washington. The diesel fuel samples come from diverse sources and include four commercial ultra-low sulfur diesel (ULSD) fuels, one gas-to-liquid (GTL) diesel fuel, six renewable diesel (RD) fuels, two shale oil (SO)-derived diesel fuels, and one oil sands (OS)-derived diesel fuel.

NMR spectroscopy is a powerful technique for quantifying both carbon and hydrogen functionalities in petroleum samples. Much of the motivation for using NMR analyses as a means of characterizing fuel samples may be found in our previous work (Alnajjar et al. 2010). Spectral range assignments and interpretation of NMR results are based on ranges and methods presented by Altgelt and Boduszynski (1994). PNNL utilizes additional multi-dimensional NMR techniques and advanced pulse sequences in

order to make thorough assessments of functional group assignments. In several cases, the methodology is under development and will be reported separately. Example data from single-bond, proton-carbon correlation (HSQC) NMR spectra are shown later in this report.

\subsection{Results and Discussions}

During the course of this investigation, fuels from diverse sources were examined. The analyses of specific fuel groupings are presented in the following subsections. In most cases these fuels were naturally grouped, but in the case of the gas-to-liquid (GTL) fuel, the closest comparison fuels were the renewable diesels, based upon the generally low aromatic content of the members of this group.

Comparisons within the group and overall comparisons between the groups were made. Each subsection includes a summary comparison table of data, as well as more detailed summary tables for that fuel group. Detailed carbon type analyses $\left({ }^{13} \mathrm{C}\left\{{ }^{1} \mathrm{H}\right\} \mathrm{NMR}\right)$ and analyses by hydrogen type $\left({ }^{1} \mathrm{H} \mathrm{NMR}\right)$ are presented in Appendix A. 
Because of the nature of this study, the fuel processing and fuel sourcing information of the sample fuels is unavailable. Coupling fuel source and fuel processing information with the NMR carbon-type analysis could provide insights into the processing conditions and catalysts used during the upgrading process.

\subsection{Comparison of Ultra-Low Sulfur Diesel Samples}

Selected percent carbon content information for ultra-low sulfur diesel (ULSD) samples is shown in Tables 1 and 2. Table 1 provides an overview of major carbon types and a summary comparison of data, while Table 2 provides a more detailed analysis of select carbon types for the ULSD samples.

As shown in Tables 1 and 2, the carbon type contents for ULSD1, ULSD2, and ULSD4 are similar. ULSD3 is distinct, having significantly lower aromatic carbon content, and higher cycloparaffinic carbon content. ULSD4 has the highest aromatic content, and ULSD1 has the highest $(n+i s o)$ paraffinic content.

Examining the aromatic region of the ${ }^{1} \mathrm{H}$ NMR shows that the majority of aromatic hydrogens are attached to monoaromatic species, but a significant fraction (about 20\%-30\%) of the aromatic hydrogens are attached to carbons in fused diaromatic systems, with the greatest relative percent of diaromatic hydrogens in ULSD2 and the least in ULSD1. ULSD 2 and ULSD 4 have the greatest number of aromatic hydrogens associated with two fused rings. From Tables 2 and 3, the number of internal or bridgehead carbons and the greater aromatic cluster size, respectively, also support the conclusion that ULSD2 and ULSD4 contain greater quantities of diaromatic species.

Table 1. Comparison of Carbon-Type Analyses of Ultra-Low Sulfur Diesels (ULSD), Normalized by Carbon Type

\begin{tabular}{cccc}
\hline & \multicolumn{3}{c}{ Carbon Content (Mole \% C) } \\
\cline { 2 - 4 } & Aromatic & Paraffinic & Cycloparaffinic \\
\hline ULSD1 & 12.9 & 55.5 & 31.5 \\
ULSD2 & 13.6 & 56.0 & 30.4 \\
ULSD3 & 7.3 & 47.0 & 45.7 \\
ULSD4 & 17.0 & 43.7 & 39.3 \\
\hline
\end{tabular}


Table 2. Summary of Ultra-Low Sulfur Diesel (ULSD) Chemical Structure Characteristics from ${ }^{13} \mathrm{C}\left\{{ }^{1} \mathrm{H}\right\}$ NMR, Normalized by Percent Carbon Type

\begin{tabular}{crrrr}
\hline & \multicolumn{3}{c}{ Carbon Content (Mole \% C) } \\
\cline { 2 - 5 } & ULSD1 & ULSD2 & ULSD3 & ULSD4 \\
\hline General Carbon Types & & & & \\
\hline Aromatic Carbon & 12.9 & 13.6 & 7.3 & 17.0 \\
Aliphatic Carbon & 87.1 & 86.4 & 92.7 & 83.0 \\
\hline $\mathrm{CH}$ Carbon & 7.0 & 7.8 & 13.8 & 10.2 \\
$\mathrm{CH}_{2}$ Carbon & 61.1 & 60.9 & 60.4 & 54.3 \\
$\mathrm{CH}_{3}$ Carbon & 18.9 & 17.7 & 18.4 & 18.5
\end{tabular}

\begin{tabular}{|c|c|c|c|c|}
\hline \multicolumn{5}{|l|}{ Aromatic Carbon Breakdown } \\
\hline Phenolic Carbon & 0 & 0 & 0.4 & 0.8 \\
\hline $\mathrm{CH}_{2} / \mathrm{CH}$ Substituted Aromatic Carbon & 3.3 & 3.0 & 1.7 & 3.8 \\
\hline Naphthene Substituted Aromatic Carbon & 1.0 & 1.1 & 0.4 & 0.5 \\
\hline $\mathrm{CH}_{3}$ Substituted Aromatic Carbon & 1.1 & 1.4 & 0.5 & 1.3 \\
\hline Internal (Bridgehead) Aromatic Carbon & 0.8 & 1.1 & 0.6 & 1.1 \\
\hline Peripheral Unsubstituted Aromatic Carbon & 6.4 & 6.5 & 3.1 & 8.3 \\
\hline Heteroaromatic Carbon & 0.3 & 0.3 & 0.6 & 1.1 \\
\hline Total Aromatic Carbon & 12.9 & 13.6 & 7.3 & 17.0 \\
\hline
\end{tabular}

\section{Paraffinic Carbor Breakdown}

\begin{tabular}{lrrrr} 
Cycloparaffinic $\mathrm{CH}$ & 5.7 & 6.8 & 10.0 & 9.1 \\
Cycloparaffinic $\mathrm{CH}_{2}$ & 21.5 & 21.6 & 30.8 & 26.9 \\
Cycloparaffinic $\mathrm{CH}_{3}$ & 4.3 & 2.0 & 4.8 & 3.3 \\
\hline Total Cycloparaffinic Carbon & $\mathbf{3 1 . 5}$ & $\mathbf{3 0 . 4}$ & $\mathbf{4 5 . 7}$ & $\mathbf{3 9 . 3}$ \\
& & & & \\
Total (n+iso) Paraffinic Carbon & $\mathbf{5 5 . 5}$ & $\mathbf{5 6 . 0}$ & $\mathbf{4 7 . 0}$ & $\mathbf{4 3 . 7}$ \\
\hline
\end{tabular}

Table 3. $\quad{ }^{1}$ H NMR Aromatic Region for Ultra-Low Sulfur Diesel (ULSD) Fuels, Breakdown of Fused, Protonated Aromatic Ring Hydrogens, Percent Results Normalized by Hydrogen Type

\begin{tabular}{lccccc} 
& & \multicolumn{4}{c}{ Aromatic Hydrogens (Mole \% H) } \\
\cline { 2 - 6 } \multicolumn{1}{c}{ Structure } & Chemical Shift & ULSD1 & ULSD2 & ULSD3 & ULSD4 \\
\hline Polyaromatic & $8.3-10.7$ & 0 & 0 & 0 & 0 \\
Triaromatic & $7.8-8.3$ & 0 & 0 & 0 & 0.1 \\
Diaromatic & $7.2-7.8$ & 0.6 & 0.9 & 0.3 & 0.8 \\
Monoaromatic & $6.2-7.2$ & 2.3 & 2.3 & 0.9 & 2.9 \\
\hline
\end{tabular}




\subsection{Comparison of Diesel Samples Derived from Shale Oil (SO) and Oil Sands (OS) Feedstocks}

Selected percent carbon content information for diesel samples derived from shale oil (SO) and oil sands (OS) feedstocks are shown in Tables 4-6. Table 4 provides an overview of major carbon types and a comparison of aromatic, paraffin, and naphthenic content for the two sample types. Table 5 provides a more detailed NMR analysis of select carbon types for the SO and OS samples.

The available NMR data show that the oil sands-derived sample is substantially different from both of the shale oil-derived samples, having a lower aromatic content and a higher cycloparaffin content. Both shale oil-derived samples are very similar. From the ${ }^{1} \mathrm{H}$ NMR results shown in Table 6 , the oil sandsderived sample, OS1, has proportionally higher diaromatic content than either of the shale oil-derived samples, SO1 and SO2. From Tables 4 and 5, SO1 has slightly higher unsubstituted aromatic carbons and an overall greater aromatic hydrogen content than $\mathrm{SO} 2$, balanced with consistently lower values for substituted aromatic carbons (methyl-, methylene-, and methine-substituted aromatic carbons, as well as naphthene-substituted aromatic carbons, such as those found in tetralin). This suggests that on average $\mathrm{SO} 2$ is more likely to have a greater number of substituted aromatic carbons per ring than SO1.

Table 4. Summary of Carbon-Type Analyses of Diesel Samples Derived from Shale Oil (SO) and Oil Sands (OS) Feedstocks, Normalized by Carbon Type

\begin{tabular}{cccc}
\hline & \multicolumn{3}{c}{ Carbon Content (Mole \% C) } \\
\cline { 2 - 4 } & Aromatic & Paraffinic & Cycloparaffinic \\
\hline SO1 & 14.6 & 60.3 & 25.1 \\
SO2 & 14.4 & 65.3 & 20.3 \\
OS1 & 11.2 & 49.3 & 39.5 \\
\hline
\end{tabular}


Table 5. Summary of Diesel Samples Derived from Shale Oil (SO) and Oil Sands (OS) Feedstocks Chemical Structure Characteristics from ${ }^{13} \mathrm{C}\left\{{ }^{1} \mathrm{H}\right\}$ NMR, Normalized by Percent Carbon Type

\begin{tabular}{crrr}
\hline & \multicolumn{3}{c}{ Carbon Content (Mole \% C) } \\
\cline { 2 - 4 } & SO1 & SO2 & OS1 \\
\hline General Carbon Types & & & \\
\hline Aromatic Carbon & 14.6 & 14.4 & 11.2 \\
Aliphatic Carbon & 85.4 & 85.6 & 88.8 \\
CH Carbon & 5.5 & 4.4 & 8.8 \\
$\mathrm{CH}_{2}$ Carbon & 59.4 & 60.6 & 55.3 \\
$\mathrm{CH}_{3}$ Carbon & 20.5 & 20.6 & 24.7
\end{tabular}

\begin{tabular}{|llll|}
\hline Aromatic Carbon Breakdown & & & \\
\hline Phenolic Carbon & 0 & 0.1 & 1.3 \\
\hline $\mathrm{CH}_{2} / \mathrm{CH}$ Substituted Aromatic Carbon & 3.3 & 3.7 & 3.0 \\
\hline $\mathrm{Naph}_{\text {thene Substituted Aromatic Carbon }}$ & 1.4 & 1.5 & 0.7 \\
\hline $\mathrm{CH}_{3}$ Substituted Aromatic Carbon & 1.0 & 1.2 & 0.8 \\
\hline Internal (Bridgehead) Aromatic Carbon & 0.6 & 0.9 & 0.7 \\
\hline Peripheral Unsubstituted Aromatic Carbon & 8.3 & 6.9 & 3.6 \\
\hline Heteroaromatic Carbon & 0 & 0 & 1.1 \\
\hline \multicolumn{1}{|c|}{ Total Aromatic Carbon } & $\mathbf{1 4 . 6}$ & $\mathbf{1 4 . 4}$ & $\mathbf{1 1 . 2}$
\end{tabular}

\section{Paraffinic Carbor Breakdown}

\begin{tabular}{lrrr} 
Cycloparaffinic $\mathrm{CH}$ & 4.5 & 3.5 & 5.8 \\
Cycloparaffinic $\mathrm{CH}_{2}$ & 17.7 & 13.1 & 29.1 \\
Cycloparaffinic $\mathrm{CH}_{3}$ & 2.9 & 3.7 & 4.6 \\
\hline Total Cycloparaffinic Carbon & 25.1 & 20.3 & 39.5 \\
Total (n + iso) Paraffinic Carbon & $\mathbf{6 0 . 3}$ & $\mathbf{6 5 . 3}$ & $\mathbf{4 9 . 3}$ \\
\hline
\end{tabular}

Table 6. $\quad{ }^{1}$ H NMR Aromatic Region for Shale Oil (SO) and Oil Sands (OS) Derived Fuels, Breakdown of Fused, Protonated Aromatic Ring Hydrogens, Percent Results Normalized by Hydrogen Type

\begin{tabular}{lcccc} 
& & \multicolumn{2}{c}{ Aromatic Hydrogens (Mole \% H) } \\
\cline { 2 - 4 } \multicolumn{1}{c}{ Structure } & Chemical Shift & SO1 & SO2 & OS1 \\
\hline Polyaromatic & $8.3-10.7$ & 0 & 0 & 0 \\
Triaromatic & $7.8-8.3$ & 0 & 0 & 0 \\
Diaromatic & $7.2-7.8$ & 0.3 & 0.2 & 0.4 \\
Monoaromatic & $6.2-7.2$ & 4.0 & 3.3 & 2.0 \\
\hline
\end{tabular}




\subsection{Comparison of Renewable Diesel (RD) and Gas-to-Liquid (GTL) Samples}

Selected percent carbon content information for diesel samples derived from biomass (RD) and gasto-liquid (GTL) feedstocks are shown in Tables 7-9. Table 7 provides an overview of major carbon types and a summary comparison of data, and Table 8 provides a more detailed NMR analysis of select carbon types for the renewable (i.e., biomass-derived) and gas-to-liquid samples. Table 9 shows that with the exception of RD3, there are no significant aromatic hydrogen resonances in this data subset.

Low aromatic carbon contents are generally to be expected in renewable and GTL feedstocks, but this is not the case for RD3, where there is a substantial aromatic contribution, similar to that found in three of the four ULSDs examined in Section 2.1. Additionally, the presence of bridgehead carbons (Table 8), coupled with ${ }^{1} \mathrm{H}$ NMR data (Table 9) showing hydrogens attached to fused di- and triaromatic ring carbon atoms, suggest a significant contribution from not only mono-aromatic species, but also fused-ring species in RD3 not present in other biomass-derived samples examined here. From Table 9, nearly half of the protonated carbons are assigned to di- and triaromatic species.

Table 7. Comparison of Carbon-Type Analyses of Renewable Diesel (RD) and a Gas-to-Liquid (GTL) Fuels, Normalized by Carbon Type

\begin{tabular}{lccc}
\hline & \multicolumn{3}{c}{ Carbon Content (Mole \% C) } \\
\cline { 2 - 4 } & Aromatic & Paraffinic & Cycloparaffinic \\
\hline RD1 & 0.6 & 92.9 & 6.5 \\
RD2 & 1.7 & 91.2 & 7.1 \\
RD3 & 11.5 & 65.7 & 22.7 \\
RD4 & 0.2 & 94.8 & 4.9 \\
RD5 & 1.9 & 59.8 & 38.2 \\
RD6 & 0.0 & 100.0 & 0.0 \\
GTL & 0.5 & 93.0 & 6.7 \\
\hline
\end{tabular}


Table 8. Summary of Renewable (RD) and Gas-to-Liquid (GTL) Diesel Chemical Structure Characteristics from ${ }^{13} \mathrm{C}\left\{{ }^{1} \mathrm{H}\right\}$ NMR, Normalized by Percent Carbon Type

\begin{tabular}{crrrrrrr}
\hline & \multicolumn{7}{c}{ Carbon Content (Mole \% C) } \\
\cline { 2 - 8 } & RD1 & RD2 & RD3 & RD4 & RD5 & RD6 & GTL \\
\hline General Carbon Types & & & & & & & \\
Aromatic Carbon & 0.6 & 1.7 & 11.5 & 0.2 & 1.9 & 0 & 0.5 \\
Aliphatic Carbon & 99.4 & 98.3 & 88.4 & 99.8 & 98.1 & 100.0 & 99.5 \\
\hline $\mathrm{CH}$ Carbon & 1.6 & 1.3 & 7.3 & 0.6 & 14.7 & 1.3 & 0.8 \\
$\mathrm{CH}_{2}$ Carbon & 78.2 & 76.9 & 65.7 & 82.4 & 62.2 & 79.7 & 78.5 \\
$\mathrm{CH}_{3}$ Carbon & 19.6 & 20.1 & 15.4 & 16.7 & 21.2 & 19.0 & 20.1
\end{tabular}

\begin{tabular}{|llllllll}
\hline Aromatic Carbon Breakdown & & & & & & \\
\hline Phenolic Carbon & 0 & 0 & 0 & 0 & 0 & 0 & 0 \\
\hline $\mathrm{CH}_{2} /$ CH Substituted Aromatic Carbon & 0 & 0.1 & 2.6 & 0.1 & 0.7 & 0 & 0 \\
\hline $\mathrm{Naphthene} \mathrm{Substituted} \mathrm{Aromatic} \mathrm{Carbon}_{\mathrm{CH}_{3} \text { Substituted Aromatic Carbon }}$ & 0 & 0 & 0.6 & 0 & 0 & 0 & 0 \\
\hline Internal (Bridgehead) Aromatic Carbon & 0 & 0 & 0.8 & 0.1 & 0 & 0 & 0 \\
\hline Peripheral Unsubstituted Aromatic Carbon & 0.3 & 0.8 & 0.6 & 0 & 0 & 0 & 0 \\
\hline Heteroaromatic Carbon & 0.3 & 0.6 & 0 & 0 & 0.9 & 0 & 0.2 \\
\hline Total Aromatic Carbon & $\mathbf{0 . 6}$ & $\mathbf{1 . 7}$ & $\mathbf{1 1 . 5}$ & $\mathbf{0 . 2}$ & $\mathbf{1 . 9}$ & $\mathbf{0}$ & $\mathbf{0 . 5}$
\end{tabular}

\begin{tabular}{|c|c|c|c|c|c|c|c|}
\hline \multicolumn{8}{|l|}{ Paraffinic Carbon Breakdown } \\
\hline Cycloparaffinic $\mathrm{CH}$ & 0.1 & 0.2 & 4.6 & 0.4 & 9.1 & 0 & 0.2 \\
\hline Cycloparaffinic $\mathrm{CH}_{2}$ & 5.9 & 6.4 & 17.2 & 4.3 & 28.8 & 0 & 6.1 \\
\hline Cycloparaffinic $\mathrm{CH}_{3}$ & 0.5 & 0.5 & 0.9 & 0.2 & 0.3 & 0 & 0.4 \\
\hline Total Cycloparaffinic Carbon & 6.5 & 7.1 & 22.7 & 4.9 & 38.2 & 0 & 6.7 \\
\hline Total (n + iso) Paraffinic Carbon & 92.9 & 91.2 & 65.7 & 94.8 & 59.8 & 100.0 & 93.0 \\
\hline
\end{tabular}

Table 9. $\quad{ }^{1}$ H NMR Aromatic Region of Renewable Diesel (RD) and a Gas-to-Liquid (GTL) Fuels,

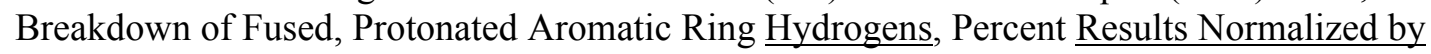
Hydrogen Type

\begin{tabular}{lcccccccc} 
& & \multicolumn{7}{c}{ Aromatic Hydrogens (Mole \% H) } \\
\cline { 2 - 8 } \multicolumn{1}{c}{ Structure } & Chemical Shift & RD1 & RD2 & RD3 & RD4 & RD5 & RD6 & GTL \\
\hline Polyaromatic & $8.3-10.7$ & 0 & 0 & 0 & 0 & 0 & 0 & 0 \\
Triaromatic & $7.8-8.3$ & 0 & 0 & 0.1 & 0 & 0 & 0 & 0 \\
Diaromatic & $7.2-7.8$ & 0 & 0 & 0.9 & 0 & 0 & 0 & 0 \\
Monoaromatic & $6.2-7.2$ & 0 & 0 & 2.3 & 0 & 0.1 & 0.1 & 0.1 \\
\hline
\end{tabular}

\subsection{Advanced Analysis Techniques}

Single-bond proton-carbon correlation (HSQC) NMR spectra have also been obtained for several of the fuels in this group, although data collection is ongoing. The aromatic region in particular can provide interesting information that can allow us to fingerprint fuels. Figure 1 shows the HSQC aromatic region for two diesel samples derived from shale oil (SO1 and SO2) and oil sands (OS1) feedstocks. As an 
initial observation, the pattern shown for the two shale oil samples (SO1 and SO2) and the ULSD sample (ULSD1), (a)-(c), respectively, show obvious similarities, which are in keeping with the statements above that these fuels are generally similar in overall makeup, with SO2 (b) and ULSD1 (c) exhibiting the most similarities. On closer examination, specific differences in peak intensity and some unique peaks can be observed for each spectrum. Of the four spectra presented, (d), the aromatic region for OS1, is most different, showing a well-defined boundary for the aromatic region, but fewer intense peaks within that boundary. When integrated, a quantitative assessment of the aromatic fuel components may be obtained, with the correlated spectra allowing better discrimination between resonances that are overlapping in the ${ }^{13} \mathrm{C}\left\{{ }^{1} \mathrm{H}\right\}$ NMR spectrum. Taken as a whole, each of the fuels presents a different distribution of components, readily obvious in the HSQC data. These clearly observable differences allow us to readily discern different fuel blends or sources, and can later be correlated to physical properties derived from molecular structures within the fuels.
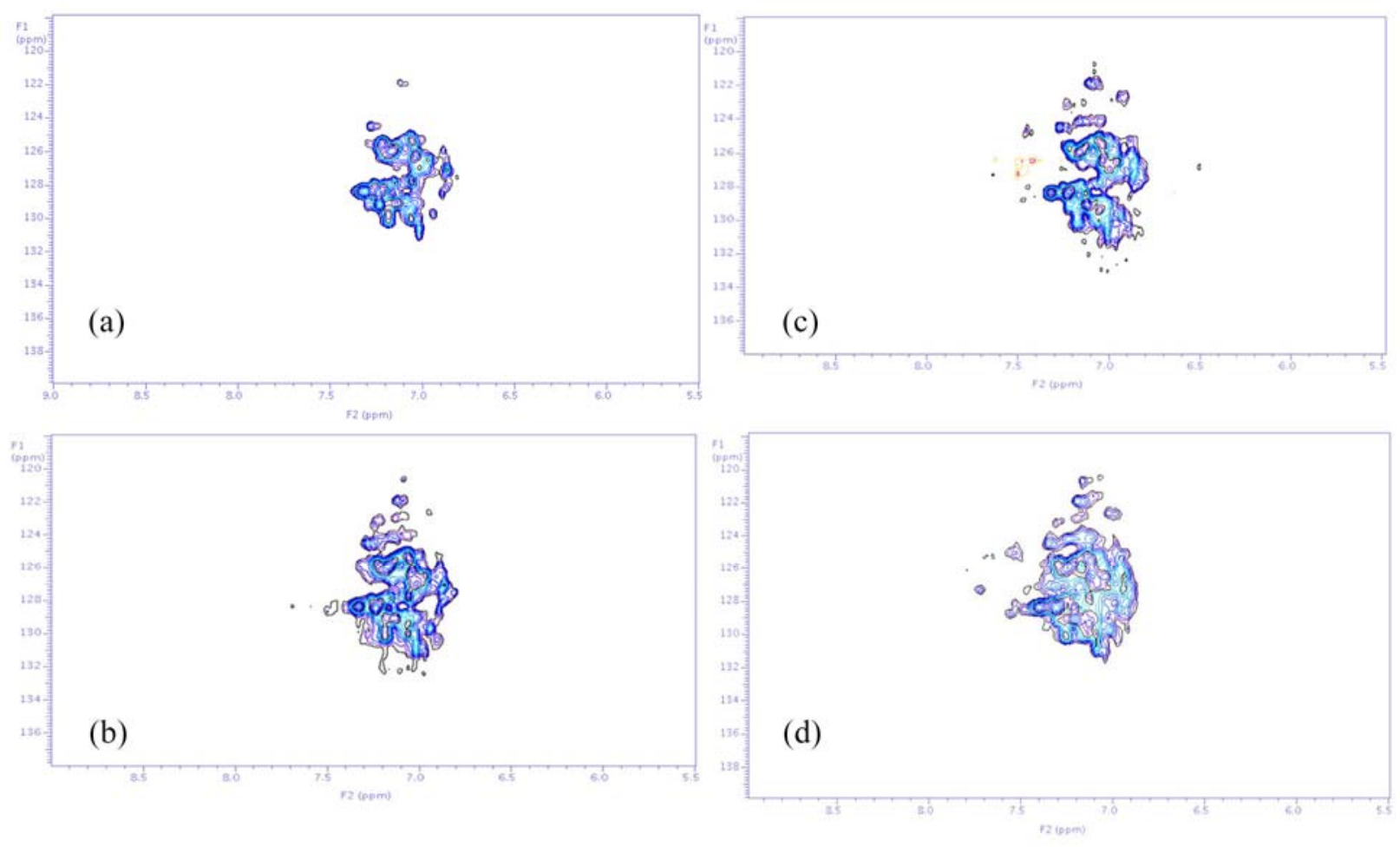

Figure 1. Single-bond, Proton-Carbon Correlation (HSQC) NMR Spectra of Fuels: (a) Shale Oilderived Diesel (SO1), (b) Shale Oil-derived Diesel (SO2), (c) Ultra-low Sulfur Diesel (ULSD1), (d) Oil Sands-derived Diesel (OS1). The vertical axis is a subset of the ${ }^{13} \mathrm{C}\left\{{ }^{1} \mathrm{H}\right\}$ NMR spectrum, and the horizontal axis is a subset of the ${ }^{1} \mathrm{H}$ NMR spectrum. Both have units of parts-per-million chemical shift.

Additional NMR techniques are available that can provide further structural information for the fuel components. Useful NMR techniques might include homonuclear ${ }^{1} \mathrm{H}$ NMR experiments, such as correlation spectroscopy (COSY) and total correlation spectroscopy (TOCSY), which could differentiate between overlapping resonances in the aromatic-aliphatic methylene regions in the ${ }^{1} \mathrm{H}$ NMR, or a homonuclear ${ }^{13} \mathrm{C}\left\{{ }^{1} \mathrm{H}\right\}$ experiment, like the "Incredible Natural-Abundance DoublE-QUAntum Transfer 
Experiment" (INADEQUATE) to determine carbon-carbon bond connectivity. Heteronuclear experiments such as single-bond proton-carbon correlation (HSQC) experiments have shown promise, so multiple-bond proton-carbon correlation (HMBC) experiments may also reveal some of the structural diversity of fuels from different sources. Additional information from these and other two-dimensional NMR techniques may be important in determining fuel structure-property relationships, and should be explored.

\subsection{Conclusions}

Overall, the fuels examined here fall into two groups. The two shale oil-derived samples and the oilsand-derived sample closely resemble the four commercial ultra-low sulfur diesels, with SO1 and SO2 most closely matched with ULSD1, ULSD2, and ULSD4, and OS1 most closely matched with ULSD3. ULSD3 differs from the other ULSD samples, having significantly lower aromatic carbon content and a higher cycloparaffinic carbon content. As might be expected, the renewable diesel fuels, with the exception of RD3, do not resemble the ULSD or alternative fuels because of their very low aromatic content, but more closely resemble the gas-to-liquid sample (GTL) in this respect. As noted previously, $\mathrm{RD} 3$, particularly with respect to the aromatic content, more closely resembles the ULSD fuels. Additionally, fused-ring aromatics are readily observable in the ULSD, SO, and OS samples, as well as RD3, and are noticeably absent in the remaining RD and GTL fuels.

\subsection{Nuclear Magnetic Resonance Method}

All quantitative ${ }^{1} \mathrm{H}$ NMR and ${ }^{13} \mathrm{C}\left\{{ }^{1} \mathrm{H}\right\}$ NMR spectra were acquired at 499.67 and $125.65 \mathrm{MHz}$, respectively, on a Varian Inova System. All spectra were recorded at $25.0^{\circ} \mathrm{C}$ in 5 -mm outer-diameter NMR tubes, spinning at $20 \mathrm{~Hz}$. Spectra were processed using analysis tools from Varian VNMRJ Version 2.2 Revision D software, or MestReNova Version 6.0.4-5850 software.

Quantitative ${ }^{13} \mathrm{C}\left\{{ }^{1} \mathrm{H}\right\}$ spectra were acquired using a $45^{\circ}$ observe pulse; acquisition and relaxation delay times of 3 and 5 seconds, respectively, with ${ }^{1} \mathrm{H}$ Waltz decoupling during the acquisition delay period for nuclear Overhauser enhancement (NOE) suppression; and $0.05 \mathrm{M} \mathrm{Cr}(\mathrm{acac})_{3}$ for $\mathrm{T}_{1}$ reduction and quenching of any residual NOE, where acac is $\mathrm{CH}_{3} \mathrm{C}(\mathrm{O}) \mathrm{CHC}(\mathrm{O}) \mathrm{CH}_{3}$. These conditions lead to an average integral uncertainty of about $\pm 2 \%$ (in carbon aromaticity). Carbon- 13 spectra are referenced to internal $\mathrm{CDCl}_{3}(77.16 \mathrm{ppm})$ (Gottlieb et al. 1997), tetramethylsilane (0 ppm), or the $\alpha$-carbon of linear long chain saturated hydrocarbons $(14.16 \mathrm{ppm})$. Samples consisted of $0.20 \mathrm{~mL}$ of fuel diluted to $1.00 \mathrm{~mL}$ in $\mathrm{CDCl}_{3}$ with $0.05 \mathrm{M} \mathrm{Cr}(\mathrm{acac})_{3}$. Spectra resulted from 1,500-6,000 scans. Line broadening of $2.5 \mathrm{~Hz}$ was used for processing spectra to improve the signal-to-noise ratio. Quantitative results were obtained by integrating each sample spectrum on two or three separate occasions to account for variation in phasing and baseline correction approaches. Results are presented as normalized averages of the integrated area for each spectral region.

Quantitative ${ }^{1} \mathrm{H}$ spectra were acquired using a $30^{\circ}$ observe pulse, with acquisition and relaxation delays of 3 and 8 seconds, respectively, for an 11-second recycle time. Samples consisted of about $50 \mathrm{mg}$ of fuel diluted to $1.00 \mathrm{~mL}$ in $\mathrm{CDCl}_{3}$. Addition of $\mathrm{Cr}(\mathrm{acac})_{3}$ did not change the integration values for the proton NMR. Measured proton ratios are relatively insensitive to conditions as long as recycle times are 
kept above about 5 seconds. Chemical shifts are referenced to internal tetramethylsilane $(0 \mathrm{ppm})$ or to internal residual $\mathrm{CHCl}_{3}$ in solvent $\mathrm{CDCl}_{3}(7.26 \mathrm{ppm}$ ) (Gottlieb et al. 1997). Spectra resulted from 128 scans. Line broadening was not used. Quantitative results were obtained from single integrations of each spectrum, because unlike the ${ }^{13} \mathrm{C}\left\{{ }^{1} \mathrm{H}\right\}$ analyses, ${ }^{1} \mathrm{H}$ seemed to be less susceptible to phasing and baseline correction variations.

Spectral range assignment and interpretation of NMR results are based on ranges and methods presented by Altgelt and Boduszynski (1994).

\subsection{References}

Alnajjar M, B Cannella, H Dettman, C Fairbridge, J Franz, T Gallant, R Gieleciak, D Hager, C Lay, S Lewis, M Ratcliff, S Sluder, J Storey, H Yin and B Zigler. 2010. Chemical and Physical Properties of the Fuels for Advanced Combustion Engines (FACE) Research Diesel Fuels. CRC Report No. FACE-1, Coordinating Research Council, Alpharetta, Georgia. Available at http://crcao.com/publications/advancedVehiclesFuelsLubricants/index.html.

Altgelt KH and MM Boduszynski. 1994. Composition and Analysis of Heavy Petroleum Fractions. Marcel Dekker, New York.

Gottlieb HE, V Kotlyar and A Nudelman. 1997. "NMR Chemical Shifts of Common Laboratory Solvents as Trace Impurities." Journal of Organic Chemistry 62(21):7512-7515. <Go to ISI>://WOS:A1997YC65700083. 
Appendix A

Complete NMR and NMR-Derived Data Tables 



\section{Appendix A}

\section{Complete NMR and NMR-Derived Data Tables}

Table A.1. Detailed Chemical Shift Regions for Normalized ${ }^{13} \mathrm{C}\left\{{ }^{1} \mathrm{H}\right\}$ Percent Composition of Ultra-Low Sulfur Diesel (ULSD) Fuels

\begin{tabular}{|c|c|c|c|c|c|}
\hline \multirow{2}{*}{$\begin{array}{l}\text { Chemical } \\
\text { Shift }\end{array}$} & \multirow[b]{2}{*}{ Structure Definition } & \multicolumn{4}{|c|}{$\% \mathrm{C}$} \\
\hline & & ULSD1 & ULSD2 & ULSD3 & ULSD4 \\
\hline $220-202$ & Ketone Carbonyl & 0 & 0 & 0 & 0 \\
\hline $202-195$ & Aldehyde Carbonyl & 0 & 0 & 0 & 0 \\
\hline 195-182 & Quinone Carboxyl & 0 & 0 & 0 & 0 \\
\hline $182-176$ & Acid Carboxyl & 0 & 0 & 0 & 0 \\
\hline $176-165$ & Ester or Amide Carboxyl & 0 & 0 & 0 & 0 \\
\hline $165-143$ & $\begin{array}{l}\text { Alkyl (other than methyl), or heteroatom (N, O, S) } \\
\text { substituted aromatic }\end{array}$ & 1.0 & 1.1 & 1.0 & 1.0 \\
\hline $143-137$ & Tertiary carbon in alkyl substituted aromatics & 2.2 & 2.0 & 1.1 & 2.6 \\
\hline $137-131$ & $\begin{array}{l}\text { Tertiary carbon in naphthalene units and methyl } \\
\text { substituted aromatics }\end{array}$ & 2.3 & 3.2 & 1.3 & 2.3 \\
\hline $131-127.5$ & $\begin{array}{l}\text { Protonated and internal aromatic carbon, substituted } \\
\text { carbon in alkenes }\left(\mathrm{R}_{2} \mathrm{C}=\mathrm{CR}_{2}\right) \text {, orth and meta } \mathrm{CH} \text { in } \\
\text { toluene }\end{array}$ & 3.0 & 2.8 & 1.1 & 3.1 \\
\hline $127.5-124$ & $\begin{array}{l}\text { Protonated and internal aromatic carbon, substituted } \\
\text { carbon in alkenes }\left(\mathrm{RHC}=\mathrm{CR}_{2}\right) \text {, para } \mathrm{CH} \text { in toluene }\end{array}$ & 2.7 & 3.3 & 1.3 & 3.7 \\
\hline 124-115 & $\begin{array}{l}\text { Protonated aromatic carbon, substituted carbon in alkenes } \\
(\mathrm{RHC}=\mathrm{CR} 2)\end{array}$ & 0 & 0.8 & 0.9 & 0.9 \\
\hline $115-95$ & Unsubstituted carbon in alkenes $\left(\mathrm{CH}_{2}=\mathrm{CR}_{2}\right)$ & 0 & 0 & 0.6 & 0.4 \\
\hline $70-60$ & $\mathrm{CH}_{2}$ adjacent to oxygen and $\mathrm{C}$ in tertiary alchols & 0 & 0 & 0 & 0 \\
\hline $60-45$ & $\begin{array}{l}\mathrm{CH} \text { adjacent to tertiary and isopropyl groups. } \mathrm{CH}_{3} \text { in } \\
\text { ether linkage }\end{array}$ & 3.1 & 3.1 & 5.7 & 3.8 \\
\hline $45-40$ & $\begin{array}{l}\mathrm{CH} \text { in allylic and benzylic groups and in joining tetralin } \\
\text { ring }\end{array}$ & 5.0 & 4.7 & 8.1 & 5.1 \\
\hline $40-36$ & $\begin{array}{l}\mathrm{CH}_{2} \text { adjacent to substituted double bonds and tertiary } \\
\text { carbon }\end{array}$ & 9.2 & 8.5 & 11.5 & 9.1 \\
\hline $36-33.5$ & $\begin{array}{l}\mathrm{CH}, \mathrm{CH}_{2} \beta \text { from secondary carbon and in cyclopentyl and } \\
\text { cyclohexyl rings }\end{array}$ & 5.6 & 5.0 & 7.6 & 6.0 \\
\hline $33.5-31$ & $\begin{array}{l}\mathrm{CH}, \mathrm{CH}_{2} \gamma \text { from } \mathrm{CH}_{3} . \mathrm{CH}_{2} \alpha \text { to allylic and beta to } \\
\text { aromatic groups }\end{array}$ & 10.3 & 10.0 & 10.8 & 10.2 \\
\hline $31-28.5$ & $\begin{array}{l}\mathrm{C} \text { in open chains. } \mathrm{CH}_{2} \text { benzylic and } \mathrm{CH}_{2} \text { not adjacent to } \\
\mathrm{CH} \text { in alkyl group }\end{array}$ & 19.4 & 20.3 & 12.0 & 16.7 \\
\hline $28.5-26.5$ & $\begin{array}{l}\mathrm{CH}, \mathrm{CH}_{2} \text { in open chains. } \mathrm{CH}_{2} \text { in cyclohexyl groups and } \\
\mathrm{CH}_{3} \text { in tert-buty ether }\end{array}$ & 5.7 & 5.3 & 6.2 & 5.8 \\
\hline $26.5-24.5$ & $\begin{array}{l}\text { Some naphthenic } \mathrm{CH}_{2} \cdot \mathrm{CH}_{2} \beta \text { in propyl, indan and } \\
\text { cyclopentyl groups }\end{array}$ & 3.1 & 3.3 & 3.8 & 3.2 \\
\hline $24.5-22$ & $\mathrm{CH}_{2} \gamma$ from terminal $\mathrm{CH}_{3} . \mathrm{CH}_{2} \beta$ in unsubstituted tetralin & 8.7 & 9.0 & 8.6 & 8.6 \\
\hline $22-20$ & $\begin{array}{l}\mathrm{CH}_{3} \alpha \text { in hydroaromatics and alkyls not shielded by } \\
\text { adjacent rings or groups }\end{array}$ & 3.5 & 3.8 & 4.7 & 3.5 \\
\hline
\end{tabular}




\begin{tabular}{clcccc}
\hline \multirow{2}{*}{$\begin{array}{c}\text { Chemical } \\
\text { Shift }\end{array}$} & \multicolumn{1}{c}{ Structure Definition } & \multicolumn{3}{c}{ \%C } \\
\cline { 3 - 6 } & \multicolumn{1}{c}{ ULSD1 } & ULSD2 & ULSD3 & ULSD4 \\
\hline $20-18$ & $\begin{array}{l}\mathrm{CH}_{3} \alpha \text { in hydroaromatics and alkyls shielded by adjacent } \\
\text { rings or groups }\end{array}$ & 4.4 & 4.1 & 4.4 & 4.2 \\
$18-15$ & $\mathrm{CH}_{3}$ in cyclohexanes and $\beta$ in ethyl aromatics and ethers & 1.3 & 1.5 & 1.8 & 1.5 \\
\hline $15-12.5$ & $\begin{array}{l}\mathrm{CH}_{3} \gamma \text { to an aromatic ring or shielded by two adjacent } \\
\text { rings or groups, chain } \alpha-\mathrm{CH}_{3}\end{array}$ & 6.4 & 6.2 & 5.1 & 6.0 \\
$12.5-5$ & $\mathrm{CH}_{3} \gamma$ to aromatic rings or ethyl substituted cyclohexanes & 2.4 & 2.0 & 2.4 & 2.4 \\
\hline
\end{tabular}

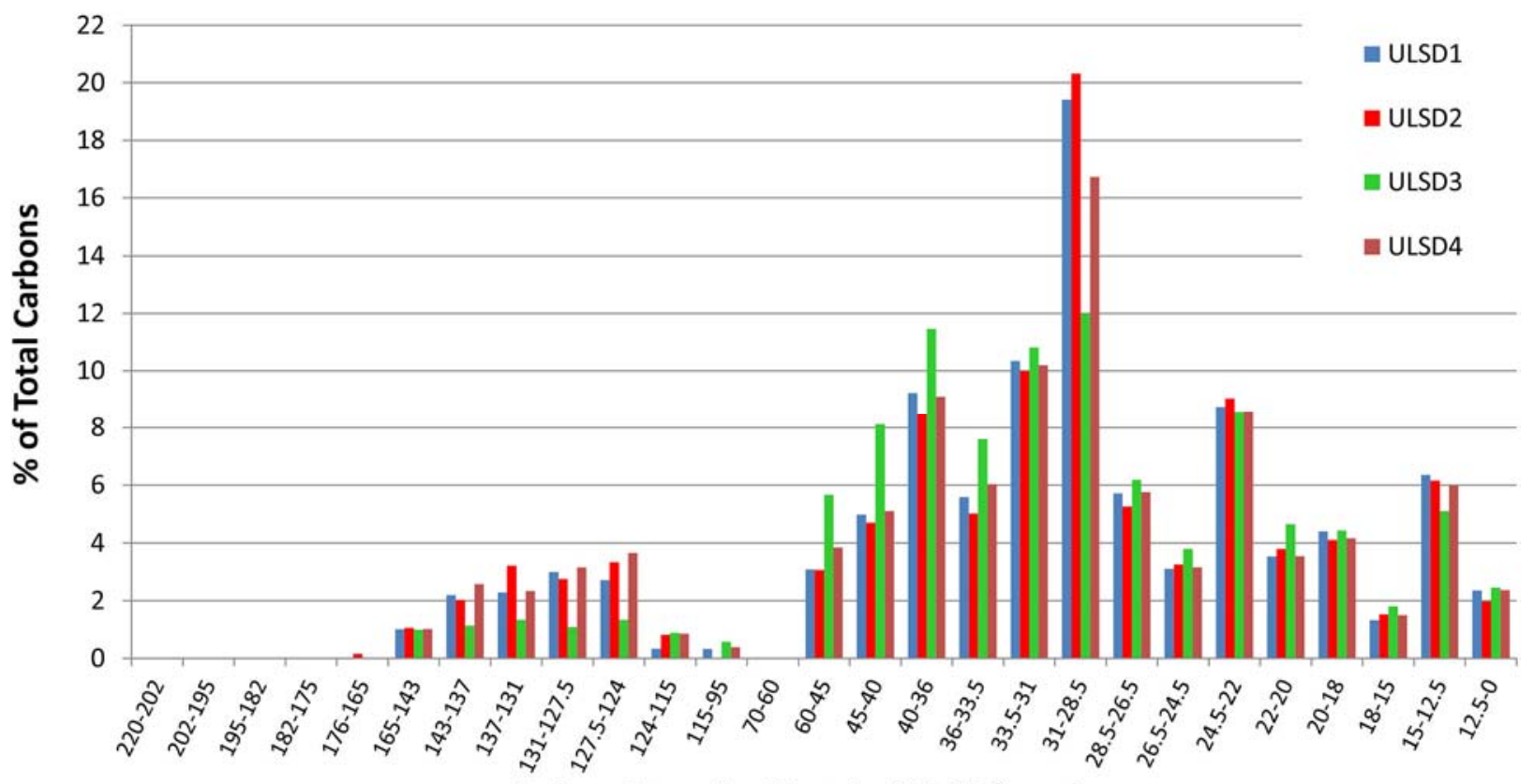

Carbon Types by Chemical Shift (ppm)

Figure A.1. Normalized Carbon Type Distribution of Ultra-Low Sulfur Diesel Fuels. The significance of each NMR chemical shift region is briefly described in Table A.1.

Table A.2. ${ }^{1}$ H NMR Comparison of Ultra-Low Sulfur Diesel (ULSD) Fuels, Normalized by Hydrogen Type

\begin{tabular}{llcccccc}
\hline Label & Structure & Definition & Chemical Shift & ULSD1 & ULSD2 & ULSD3 & ULSD4 \\
\hline HA1 & Polyaromatic & $\mathrm{H}$ & $7.4-10.7$ & 0.2 & 0.6 & 0.1 & 0.4 \\
HA2 & Monoaromatic & $\mathrm{H}$ & $7.4-6.2$ & 2.7 & 2.7 & 1.0 & 3.4 \\
HO1 & Olefinic & $\mathrm{CH}$ & $5.1-6.2$ & 0 & 0 & 0 & 0 \\
HO2 & Olefinic & $\mathrm{CH}_{2}$ & $4.8-5.1$ & 0 & 0 & 0 & 0 \\
HO3 & Olefinic & $\mathrm{CH}_{3}$ & $4.3-4.8$ & 0 & 0 & 0 & 0 \\
HP1 & $\alpha$-to-aromatic & $\mathrm{CH}_{2}$ & $2.4-4.3$ & 2.9 & 3.8 & 1.4 & 3.9 \\
HP2 & $\alpha$-to-aromatic & $\mathrm{CH}_{3}$ & $2.0-2.4$ & 3.2 & 3.5 & 1.9 & 3.9 \\
HP3 & Aliphatic & $\mathrm{CH}_{2}$ & $1.09-2.0$ & 57.9 & 57.9 & 53.3 & 54.8 \\
HP4 & Aliphatic & $\mathrm{CH}_{3}$ & $0.5-1.09$ & 33.0 & 31.4 & 42.3 & 33.6 \\
\hline
\end{tabular}


Table A.3. Detailed Chemical Shift Regions for Normalized ${ }^{13} \mathrm{C}\left\{{ }^{1} \mathrm{H}\right\}$ Percent Composition of Diesel Fuels from Oils Derived from Shale Oil (SO) and Oil Sands (OS) Feedstocks

\begin{tabular}{|c|c|c|c|c|}
\hline \multirow{2}{*}{$\begin{array}{l}\text { Chemical } \\
\text { Shift }\end{array}$} & \multirow[b]{2}{*}{ Structure Definition } & \multicolumn{3}{|c|}{$\% \mathrm{C}$} \\
\hline & & SO1 & SO2 & OS1 \\
\hline $220-202$ & Ketone Carbonyl & 0 & 0 & 0 \\
\hline $202-195$ & Aldehyde Carbonyl & 0 & 0 & 0 \\
\hline $195-182$ & Quinone Carboxyl & 0 & 0 & 0.1 \\
\hline $182-176$ & Acid Carboxyl & 0 & 0 & 0 \\
\hline $176-165$ & Ester or Amide Carboxyl & 0 & 0 & 0 \\
\hline $165-143$ & Alkyl (other than methyl), or heteroatom $(\mathrm{N}, \mathrm{O}, \mathrm{S})$ substituted aromatic & 0.9 & 1.5 & 0.9 \\
\hline $143-137$ & Tertiary carbon in alkyl substituted aromatics & 2.4 & 2.3 & 1.4 \\
\hline $137-131$ & Tertiary carbon in naphthalene units and methyl substituted aromatics & 2.7 & 3.0 & 1.6 \\
\hline $131-127.5$ & $\begin{array}{l}\text { Protonated and internal aromatic carbon, substituted carbon in alkenes } \\
\left(\mathrm{R}_{2} \mathrm{C}=\mathrm{CR}_{2}\right) \text {, orth and meta } \mathrm{CH} \text { in toluene }\end{array}$ & 5.1 & 3.4 & 2.2 \\
\hline $127.5-124$ & $\begin{array}{l}\text { Protonated and internal aromatic carbon, substituted carbon in alkenes } \\
\left(\mathrm{RHC}=\mathrm{CR}_{2}\right) \text {, para } \mathrm{CH} \text { in toluene }\end{array}$ & 3.8 & 3.4 & 1.7 \\
\hline $124-115$ & Protonated aromatic carbon, substituted carbon in alkenes (RHC $=\mathrm{CR} 2)$ & 0.3 & 0.5 & 0.3 \\
\hline $115-95$ & Unsubstituted carbon in alkenes $\left(\mathrm{CH}_{2}=\mathrm{CR}_{2}\right)$ & 0 & 0 & 0.2 \\
\hline $70-60$ & $\mathrm{CH}_{2}$ adjacent to oxygen and $\mathrm{C}$ in tertiary alchols & 0 & 0 & 0 \\
\hline $60-45$ & $\mathrm{CH}$ adjacent to tertiary and isopropyl groups. $\mathrm{CH}_{3}$ in ether linkage & 1.8 & 1.3 & 4.3 \\
\hline $45-40$ & $\mathrm{CH}$ in allylic and benzylic groups and in joining tetralin ring & 2.9 & 2.7 & 7.9 \\
\hline $40-36$ & $\mathrm{CH}_{2}$ adjacent to substituted double bonds and tertiary carbon & 6.9 & 7.0 & 10.4 \\
\hline $36-33.5$ & $\mathrm{CH}, \mathrm{CH}_{2} \beta$ from secondary carbon and in cyclopentyl and cyclohexyl rings & 4.0 & 3.7 & 7.2 \\
\hline $33.5-31$ & $\mathrm{CH}, \mathrm{CH}_{2} \gamma$ from $\mathrm{CH}_{3}$. $\mathrm{CH}_{2} \alpha$ to allylic and beta to aromatic groups & 11.6 & 11.0 & 10.6 \\
\hline $31-28.5$ & $\mathrm{C}$ in open chains. $\mathrm{CH}_{2}$ benzylic and $\mathrm{CH}_{2}$ not adjacent to $\mathrm{CH}$ in alkyl group & 18.4 & 21.2 & 12.1 \\
\hline $28.5-26.5$ & $\mathrm{CH}, \mathrm{CH}_{2}$ in open chains. $\mathrm{CH}_{2}$ in cyclohexyl groups and $\mathrm{CH}_{3}$ in tert-buty ether & 4.3 & 4.6 & 6.0 \\
\hline $26.5-24.5$ & Some naphthenic $\mathrm{CH}_{2} . \mathrm{CH}_{2} \beta$ in propyl, indan and cyclopentyl groups & 2.9 & 3.0 & 4.2 \\
\hline $24.5-22$ & $\mathrm{CH}_{2} \gamma$ from terminal $\mathrm{CH}_{3} . \mathrm{CH}_{2} \beta$ in unsubstituted tetralin & 11.5 & 11.1 & 8.2 \\
\hline $22-20$ & $\mathrm{CH}_{3} \alpha$ in hydroaromatics and alkyls not shielded by adjacent rings or groups & 4.4 & 4.1 & 4.6 \\
\hline $20-18$ & $\mathrm{CH}_{3} \alpha$ in hydroaromatics and alkyls shielded by adjacent rings or groups & 4.0 & 4.3 & 5.0 \\
\hline $18-15$ & $\mathrm{CH}_{3}$ in cyclohexanes and $\beta$ in ethyl aromatics and ethers & 1.4 & 1.3 & 1.7 \\
\hline $15-12.5$ & $\begin{array}{l}\mathrm{CH}_{3} \gamma \text { to an aromatic ring or shielded by two adjacent rings or groups, chain } \\
\alpha-\mathrm{CH}_{3}\end{array}$ & 9.3 & 8.7 & 6.2 \\
\hline $12.5-5$ & $\mathrm{CH}_{3} \gamma$ to aromatic rings or ethyl substituted cyclohexanes & 1.5 & 1.7 & 3.4 \\
\hline
\end{tabular}




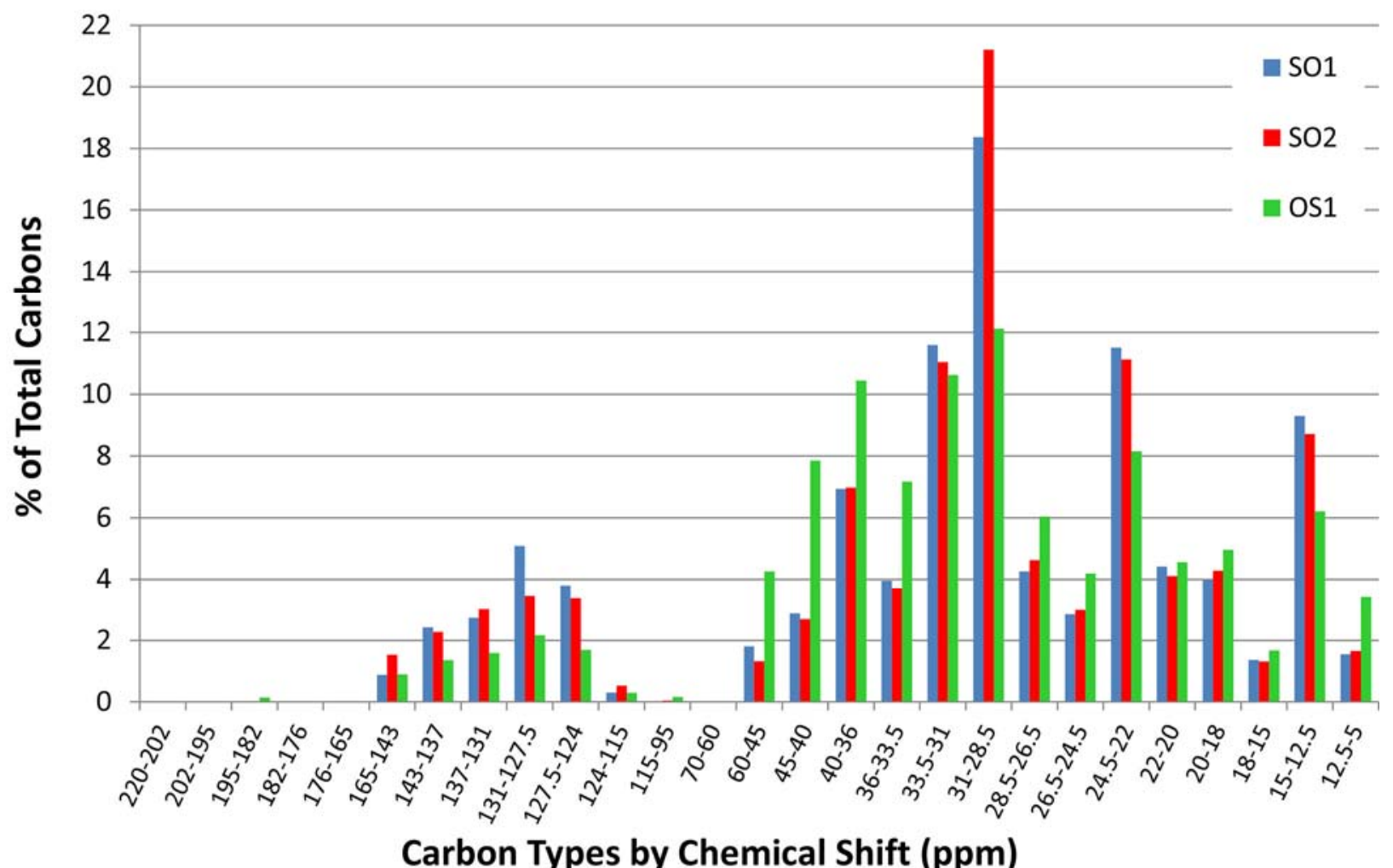

Figure A.2. Normalized Carbon Type Distribution of Diesel Fuels from Oils Derived from Shale Oil (SO) and Oil Sands (OS) Feedstocks. The significance of each NMR chemical shift region is briefly described in Table A.3.

Table A.4. ${ }^{1}$ H NMR Comparison of Diesel Fuels from Oils Derived from Shale Oil (SO) and Oil Sands (OS) Feedstocks, Normalized by Hydrogen Type

\begin{tabular}{llccccc}
\hline & & & & \multicolumn{3}{c}{ Hydrogen Content (Mole \% H) } \\
\cline { 6 - 7 } Label & Structure & Definition & Chemical Shift & OS1 & SO1 & SO2 \\
\hline HA1 & Polyaromatic & $\mathrm{H}$ & $7.4-10.7$ & 0.1 & 0.1 & 0.1 \\
HA2 & Monoaromatic & $\mathrm{H}$ & $7.4-6.2$ & 2.2 & 4.2 & 3.4 \\
HO1 & Olefinic & $\mathrm{CH}$ & $5.1-6.2$ & 0 & 0 & 0 \\
HO2 & Olefinic & $\mathrm{CH}_{2}$ & $4.8-5.1$ & 0 & 0 & 0 \\
HO3 & Olefinic & $\mathrm{CH}_{3}$ & $4.3-4.8$ & 0 & 0 & 0 \\
HP1 & a-to-aromatic & $\mathrm{CH}_{2}$ & $2.4-4.3$ & 2.5 & 2.8 & 3.4 \\
HP2 & $\alpha$-to-aromatic & $\mathrm{CH}_{3}$ & $2.0-2.4$ & 3.1 & 5.5 & 4.8 \\
HP3 & Aliphatic & $\mathrm{CH}_{2}$ & $1.09-2.0$ & 53.2 & 52.4 & 54.6 \\
HP4 & Aliphatic & $\mathrm{CH}_{3}$ & $0.5-1.09$ & 38.7 & 35.0 & 33.7 \\
\hline
\end{tabular}


Table A.5. Detailed Chemical Shift Regions for Normalized ${ }^{13} \mathrm{C}\left\{{ }^{1} \mathrm{H}\right\}$ Percent Composition of Renewable Diesel (RD) and a Gas-to-Liquid (GTL) Fuels

\begin{tabular}{|c|c|c|c|c|c|c|c|c|}
\hline \multirow{2}{*}{$\begin{array}{l}\text { Chemical } \\
\text { Shift }\end{array}$} & \multirow[b]{2}{*}{ Structure Definition } & \multicolumn{7}{|c|}{$\% \mathrm{C}$} \\
\hline & & RD1 & RD2 & RD3 & RD4 & RD5 & RD6 & GTL \\
\hline $220-202$ & Ketone Carbonyl & 0 & 0 & 0 & $\overline{0}$ & 0 & $\overline{0}$ & 0 \\
\hline 202-195 & Aldehyde Carbonyl & 0 & 0 & 0 & 0 & 0 & 0 & 0 \\
\hline $195-182$ & Quinone Carboxyl & 0 & 0 & 0 & 0 & 0 & 0 & 0 \\
\hline $182-176$ & Acid Carboxyl & 0 & 0 & 0 & 0 & 0 & 0 & 0 \\
\hline $176-165$ & Ester or Amide Carboxyl & 0 & 0 & 0 & 0 & 0 & 0 & 0 \\
\hline $165-143$ & $\begin{array}{l}\text { Alkyl (other than methyl), or heteroatom }(\mathrm{N}, \mathrm{O}, \mathrm{S}) \\
\text { substituted aromatic }\end{array}$ & 0 & 0.1 & 0.8 & 0 & 0 & 0 & 0 \\
\hline 143-137 & Tertiary carbon in alkyl substituted aromatics & 0 & 0 & 1.8 & 0 & 0.2 & 0 & 0 \\
\hline 137-131 & $\begin{array}{l}\text { Tertiary carbon in naphthalene units and methyl } \\
\text { substituted aromatics }\end{array}$ & 0 & 0.1 & 1.9 & 0.1 & 0.1 & 0 & 0.1 \\
\hline $131-127.5$ & $\begin{array}{l}\text { Protonated and internal aromatic carbon, } \\
\text { substituted carbon in alkenes }\left(\mathrm{R}_{2} \mathrm{C}=\mathrm{CR}_{2}\right) \text {, orth and } \\
\text { meta } \mathrm{CH} \text { in toluene }\end{array}$ & 0 & 0.1 & 2.7 & 0 & 0.2 & 0 & 0 \\
\hline $127.5-124$ & $\begin{array}{l}\text { Protonated and internal aromatic carbon, } \\
\text { substituted carbon in alkenes }\left(\mathrm{RHC}=\mathrm{CR}_{2}\right) \text {, para } \\
\mathrm{CH} \text { in toluene }\end{array}$ & 0.1 & 0.1 & 3.4 & 0 & 0 & 0 & 0.1 \\
\hline $124-115$ & $\begin{array}{l}\text { Protonated aromatic carbon, substituted carbon in } \\
\text { alkenes }(\mathrm{RHC}=\mathrm{CR} 2)\end{array}$ & 0.1 & 0.3 & 0.9 & 0 & 0 & 0 & 0.1 \\
\hline $115-95$ & Unsubstituted carbon in alkenes $\left(\mathrm{CH}_{2}=\mathrm{CR}_{2}\right)$ & 0.1 & 0.3 & 0 & 0 & 1.6 & 0 & 0 \\
\hline $70-60$ & $\mathrm{CH}_{2}$ adjacent to oxygen and $\mathrm{C}$ in tertiary alchols & 0 & 0 & 0 & 0.2 & 0.5 & 0 & 0.1 \\
\hline $60-45$ & $\begin{array}{l}\mathrm{CH} \text { adjacent to tertiary and isopropyl groups. } \mathrm{CH}_{3} \\
\text { in ether linkage }\end{array}$ & 0.4 & 0.2 & 2.9 & 0.3 & 6.3 & 0.2 & 0.2 \\
\hline $45-40$ & $\begin{array}{l}\mathrm{CH} \text { in allylic and benzylic groups and in joining } \\
\text { tetralin ring }\end{array}$ & 1.4 & 1.3 & 4.3 & 0.3 & 8.8 & 1.1 & 1.3 \\
\hline $40-36$ & $\begin{array}{l}\mathrm{CH}_{2} \text { adjacent to substituted double bonds and } \\
\text { tertiary carbon }\end{array}$ & 8.8 & 10.4 & 6.0 & 10.0 & 11.3 & 9.2 & 7.6 \\
\hline $36-33.5$ & $\begin{array}{l}\mathrm{CH}, \mathrm{CH}_{2} \beta \text { from secondary carbon and in } \\
\text { cyclopentyl and cyclohexyl rings }\end{array}$ & 3.8 & 4.6 & 4.3 & 1.4 & 7.4 & 3.9 & 3.3 \\
\hline $33.5-31$ & $\begin{array}{l}\mathrm{CH}, \mathrm{CH}_{2} \gamma \text { from } \mathrm{CH}_{3} . \mathrm{CH}_{2} \alpha \text { to allylic and beta to } \\
\text { aromatic groups }\end{array}$ & 12.3 & 12.5 & 13.0 & 12.8 & 12.7 & 12.2 & 14.1 \\
\hline $31-28.5$ & $\begin{array}{l}\mathrm{C} \text { in open chains. } \mathrm{CH}_{2} \text { benzylic and } \mathrm{CH}_{2} \text { not } \\
\text { adjacent to } \mathrm{CH} \text { in alkyl group }\end{array}$ & 33.2 & 27.7 & 25.2 & 37.3 & 10.5 & 33.0 & 34.6 \\
\hline $28.5-26.5$ & $\begin{array}{l}\mathrm{CH}, \mathrm{CH}_{2} \text { in open chains. } \mathrm{CH}_{2} \text { in cyclohexyl } \\
\text { groups and } \mathrm{CH}_{3} \text { in tert-buty ether }\end{array}$ & 7.0 & 8.1 & 4.1 & 9.3 & 6.9 & 7.7 & 5.5 \\
\hline $26.5-24.5$ & $\begin{array}{l}\text { Some naphthenic } \mathrm{CH}_{2} \cdot \mathrm{CH}_{2} \beta \text { in propyl, indan and } \\
\text { cyclopentyl groups }\end{array}$ & 2.1 & 2.5 & 3.2 & 0.8 & 5.4 & 2.3 & 1.4 \\
\hline $24.5-22$ & $\begin{array}{l}\mathrm{CH}_{2} \gamma \text { from terminal } \mathrm{CH}_{3} . \mathrm{CH}_{2} \beta \text { in unsubstituted } \\
\text { tetralin }\end{array}$ & 11.6 & 11.7 & 9.9 & 10.8 & 7.8 & 11.4 & 13.4 \\
\hline $22-20$ & $\begin{array}{l}\mathrm{CH}_{3} \alpha \text { in hydroaromatics and alkyls not shielded } \\
\text { by adjacent rings or groups }\end{array}$ & 1.3 & 1.4 & 2.5 & 1.0 & 4.8 & 1.4 & 0.9 \\
\hline $20-18$ & $\begin{array}{l}\mathrm{CH}_{3} \alpha \text { in hydroaromatics and alkyls shielded by } \\
\text { adjacent rings or groups }\end{array}$ & 4.5 & 5.2 & 2.0 & 4.8 & 3.7 & 4.8 & 3.4 \\
\hline $18-15$ & $\begin{array}{l}\mathrm{CH}_{3} \text { in cyclohexanes and } \beta \text { in ethyl aromatics and } \\
\text { ethers }\end{array}$ & 0.6 & 0.5 & 0.8 & 0.3 & 1.0 & 0.6 & 0.1 \\
\hline $15-12.5$ & $\begin{array}{l}\mathrm{CH}_{3} \gamma \text { to an aromatic ring or shielded by two } \\
\text { adjacent rings or groups, chain } \alpha-\mathrm{CH}_{3}\end{array}$ & 9.9 & 10.0 & 9.3 & 9.3 & 7.1 & 9.7 & 11.8 \\
\hline $12.5-5$ & $\begin{array}{l}\mathrm{CH}_{3} \gamma \text { to aromatic rings or ethyl substituted } \\
\text { cyclohexanes }\end{array}$ & 2.6 & 2.8 & 0.9 & 1.4 & 3.9 & 2.6 & 1.9 \\
\hline
\end{tabular}




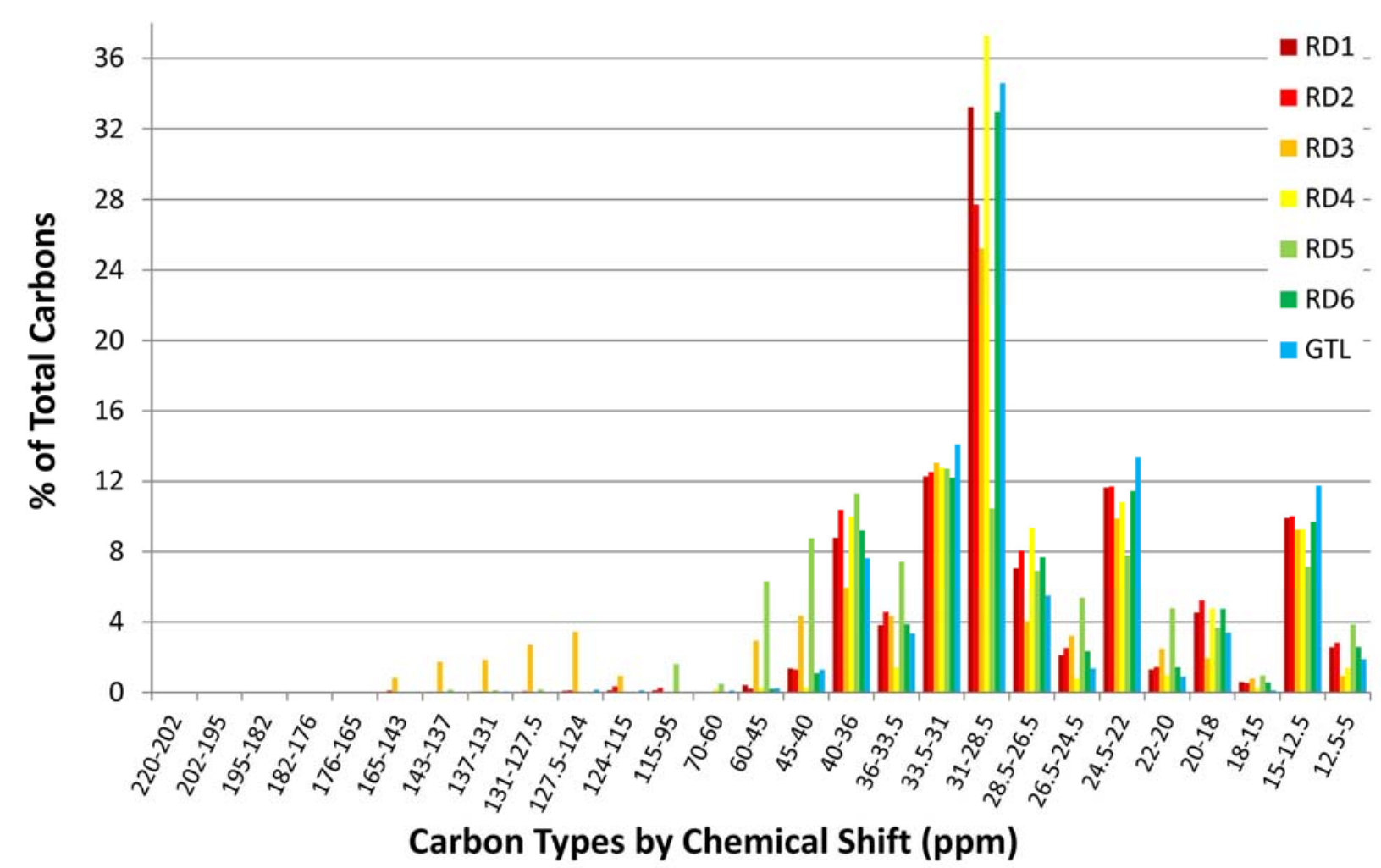

Figure A.3. Normalized Carbon Type Distribution of Renewable Diesel (RD) and a Gas-to-Liquid (GTL) Fuels. The significance of each NMR chemical shift region is briefly described in Table A.5.

Table A.6. ${ }^{1} \mathrm{H}$ NMR Comparison of Renewable Diesel (RD) and a Gas-to-Liquid (GTL) Fuels, Normalized by Hydrogen Type

\begin{tabular}{|c|c|c|c|c|c|c|c|c|c|c|}
\hline \multirow[b]{2}{*}{ Label } & \multirow[b]{2}{*}{ Structure } & \multirow[b]{2}{*}{ Definition } & \multirow{2}{*}{$\begin{array}{c}\text { Chemical } \\
\text { Shift }\end{array}$} & \multicolumn{7}{|c|}{ Hydrogen Content (Mole \% H) } \\
\hline & & & & RD-1 & RD-2 & RD-3 & RD-4 & RD-5 & RD-6 & GTL \\
\hline HA1 & Polyaromatic & $\mathrm{H}$ & $7.4-10.7$ & 0 & 0 & 0.5 & 0 & 0 & 0 & 0 \\
\hline HA2 & Monoaromatic & $\mathrm{H}$ & $7.4-6.2$ & 0 & 0 & 2.8 & 0 & 0.1 & 0.1 & 0.1 \\
\hline $\mathrm{HO} 1$ & Olefinic & $\mathrm{CH}$ & $5.1-6.2$ & 0 & 0 & 0.1 & 0 & 0 & 0 & 0 \\
\hline $\mathrm{HO} 2$ & Olefinic & $\mathrm{CH}_{2}$ & $4.8-5.1$ & 0 & 0 & 0 & 0 & 0 & 0 & 0 \\
\hline $\mathrm{HO} 3$ & Olefinic & $\mathrm{CH}_{3}$ & $4.3-4.8$ & 0 & 0 & 0 & 0 & 0 & 0 & 0 \\
\hline HP1 & $\alpha$-to-aromatic & $\mathrm{CH}_{2}$ & $2.4-4.3$ & 0 & 0.1 & 3.1 & 0 & 0.5 & 0.2 & 0 \\
\hline HP2 & $\alpha$-to-aromatic & $\mathrm{CH}_{3}$ & $2.0-2.4$ & 0.1 & 0.1 & 2.9 & 0 & 1.1 & 0.3 & 0.1 \\
\hline HP3 & Aliphatic & $\mathrm{CH}_{2}$ & $1.09-2.0$ & 67.4 & 65.5 & 66.7 & 71.8 & 60.3 & 66.6 & 68.4 \\
\hline HP4 & Aliphatic & $\mathrm{CH}_{3}$ & $0.5-1.09$ & 32.5 & 34.4 & 23.9 & 28.8 & 37.9 & 32.9 & 31.3 \\
\hline
\end{tabular}





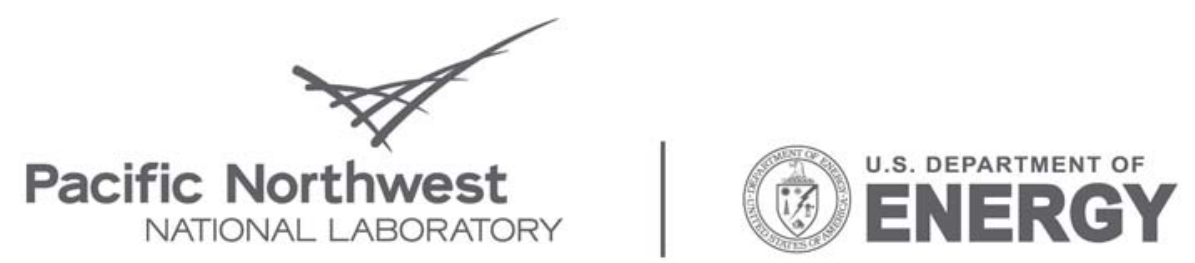

Proudly Operated by Battelle Since 1965

902 Battelle Boulevard

P.O. Box 999

Richland, WA 99352

1-888-375-PNNL (7665)

www.pnl.gov 